\title{
Efficacy of a pegaspargase-based regimen in the treatment of newly-diagnosed extranodal natural killer/T-cell lymphoma
}

\author{
L. LI", C. ZHANG ${ }^{\ddagger}$, L. ZHANG, X. LI, J. J. WU, Z. C. SUN, X. R. FU, X. H. WANG, Y. CHANG, R. WANG, Y. J. QIU, M. Z. ZHANG* \\ Department of Oncology, the First Affiliated Hospital of Zhengzhou University, Zhengzhou 450052, Henan Province, P. R. China \\ *Correspondence: mingzhi_zhang2013@outlook.com \\ ${ }^{*}$ Contributed equally to this work.
}

Received June 25, 2013 / Accepted August 20, 2013

\begin{abstract}
Extranodal natural killer (NK)/T-cell lymphoma (ENKL) is an aggressive neoplasm with poor prognosis. Currently, there is no consensus on the optimal treatment of this disease. In this study, we report the efficacy of a pegaspargase (PEG-Asp)based chemotherapy, a DDGP regimen (PEG-Asp, dexamethasone, cisplatin, gemcitabine), for the treatment of newly-diagnosed ENKL. From August 2010 to May 2012, 12 patients with newly-diagnosed stage II - IV ENKL were initially treated with a DDGP regimen in our center. Ten patients (10/12, 83.3\%) achieved complete response (CR) and two (2/12, 16.7\%) achieved partial response (PR). The objective overall response rate (ORR) was $100 \%$. Three patients (3/12, 25.0\%) relapsed, and as a result, two died of disease. Eight patients (8/12, 66.7\%) were alive with no evidence of disease (NOD) after a median follow-up of 19 months (range 16 - 31 months). Hematologic toxicity was the most frequent toxicity reported in this study. Grade 3/4 leukopenia and neutropenia were common and both occurred in eight patients $(8 / 12,66.7 \%)$, respectively. Additionally, six patients $(6 / 12,50.0 \%)$ experienced grade $3 / 4$ thrombocytopenia and three $(3 / 12,25.0 \%)$ experienced grade $3 / 4$ anemia. However, no patient died of hematologic toxicity. Our results demonstrate the significant efficacy and safety profile of a DDGP regimen in the treatment of newly-diagnosed ENKL, and indicate the potential of this regimen as a first-line therapy against this disease.
\end{abstract}

Key words: pegaspargase, extranodal NK/T-cell lymphoma, non-Hodgkin's lymphoma, medical oncology

Extranodal natural killer/T-cell lymphoma (ENKL), nasal type, is a rare type of non-Hodgkin's lymphoma (NHL) that accounts for less than $2 \%$ of all NHLs and occurs more frequently in Asia and South America than in Europe and North America [1]. ENKL is highly associated with Epstein-Barr virus (EBV) and is considered to originate from natural killer (NK) cells or,

Abbreviations: ALL, acute lymphoblast leukemia; ALT, aminotransferase; APTT, activated partial thromboplastin time; BUN, blood urea nitrogen; CHOP regimen, cyclophosphamide + vincristine + adriamycin + prednisone; $\mathrm{CR}$, complete response; DDGP regimen, pegaspargase + dexamethasone + cisplatin + gemcitabine; EBV, Epstein-Barr virus; ECG, electrocardiogram; ENKL, extranodal natural killer/T-cell lymphoma; DFS, disease-free survival; DOD, died of disease; IPI score, International Prognostic Index score; L-ASP, L-asparaginase; NHL, non-Hodgkin's lymphoma; NOD, no evidence of disease; NR, no response; ORR, overall response rate; OS, overall survival; PEG, polyethylene glycol; PEG-Asp, pegaspargase; P-gp, P-glycoprotein; PR, partial response, RT, radiotherapy; TC, total cholesterol; WHO, World Health Organization occasionally, from subsets of $\gamma \delta$ or $\alpha \beta$ cytotoxic T cells [2]. It has two clinical entities, nasal and extra nasal ENKL. Although these two entities differ in clinical presentation, treatment, and prognosis $[3,4]$, they have the same histological and immunophenotypical properties and are therefore classified in the same category according to the World Health Organization (WHO) classification of lymphomas [5].

For the treatment of ENKL, conventional chemotherapies for other aggressive lymphomas, such as $\mathrm{CHOP}$ regimens and CHOP-like regiments (cyclophosphamide, vincristine, adriamycin, prednisone), usually provide poor clinical outcomes due to the frequent multidrug resistance caused by ENKL tumor cell expression of P-glycoprotein (P-gp) [6]. According to a previous report, the complete response (CR) rate of the $\mathrm{CHOP}$ regimen alone in newly-diagnosed ENKL patients was less than 33\%, and two-year disease-free survival (DFS) and overall survival (OS) rates were $23 \%$ and $44 \%$, respectively [7]. Currently, there is no consensus on the optimal treatment of 
ENKL, and no therapy is considered standard. Physicians are actively looking for new chemotherapeutic regimens with high efficacy and low toxicity for the treatment of ENKL, and the identification of such a regimen would be an important initial step in improving treatment outcomes.

Recently, several studies have reported the remarkable efficacy and safety of L-asparaginase (L-ASP)-based regimens in patients with newly-diagnosed or relapsed/refractory ENKL [8-10]. However, serious hypersensitivity reactions can occur in hypersensitive patients, who account for $10 \%$ of the patient population and thus limit the clinical application of L-Asp-based regimens [11]. An additional disadvantage, the short plasma half-life of L-Asp causes frequent dosing that is an inconvenience to patients and clinicians. Pegaspargase (PEG-Asp) is a modified form of native E. coli asparaginase in which the enzyme is covalently linked to polyethylene glycol (PEG). The modification retains nearly $50 \%$ of the initial activity but greatly decreases the immunogenicity of L-Asp, thus significantly reducing the risk of hypersensitivity reactions [12-14]. Furthermore, PEG-Asp has 5- to 10-fold increase in plasma half-life when compared with L-Asp, which allows for a considerable reduction in the frequency of drug administration for patients [15].

PEG-Asp has been approved for the treatment of acute lymphoblast leukemia (ALL) and already become the first-line agent for ALL [16]; however, there are quite few reports on the application of PEG-Asp or PEG-Asp-based regimens to the treatment of ENKL. Here, we retrospectively report our experience in employing a new PEG-Asp-based regimen in the treatment of 12 Chinese patients with newly-diagnosed ENKL at various stages.

\section{Patients and methods}

Twelve patients with newly-diagnosed ENKL were treated in the Lymphoma Center of the First Affiliated Hospital of Zhengzhou University from August 2010 to May 2012. All patients were fully informed about the nature and possible toxicities of the treatment protocol and signed the informed consent form. The inclusion criteria were: (1) histopathologic diagnosis of ENKL based on both morphological and immunohistological criteria as stated in the WHO classification of lymphomas [5]; (2) proven NK/T-cell type by immuneohistochemistry (cytoplasmic CD3ع+, CD20-phenotype, a cytotoxic

Table 1. The DDGP regimen used in this study.

\begin{tabular}{llll}
\hline Agents & Dose & Route & Timing of treatment \\
\hline PEG-asparaginase & $2500 \mathrm{IU} / \mathrm{m}^{2}$ & IM & Day 1 \\
Gemcitabine & $800 \mathrm{mg} / \mathrm{m}^{2}$ & IV & Day 1 and day 8 \\
Cisplatin & $20 \mathrm{mg} / \mathrm{m}^{2}$ & IV & Days $1-4$ \\
Dexamethasone & $12 \mathrm{mg} / \mathrm{m}^{2}$ & IV & Days $1-5$ \\
\hline
\end{tabular}

Abbreviations: IM, intramuscularly; IV, intravenously

Cycles were repeated every 21 days profile, and markers of EBV by in situ hybridization); (3) primary tumor site was in the nasopharyngeal region or another extra nodal site. All patients were independently reviewed and confirmed by two expert pathologists.

The pretreatment staging procedures included obtaining a history and physical examination, routine blood tests, and serum chemistry profile. Computed tomography (CT) scans of the head, neck, thorax, and abdomen were performed to determine the extent of the primary lesion. In addition, bone marrow aspiration and biopsy were also carried out.

All patients received a PEG-Asp-based regimen (DDGP regimen) consisting of PEG-Asp (Pegaspargase Injection, Jiangsu Hengrui Medicine Co., Ltd., Lianyungang, China), dexamethasone (Dexamethasone Acetate Injection, Chengdu Tiantaishan Pharmaceutical Co., Ltd., Chengdu, China), cisplatin (Cisplatin Injection, Qilu Pharmaceutical Co., Ltd., Jinan, China), and gemcitabine (Gemzar ${ }^{\circledR}$, Eli Lilly, Indianapolis, USA). The specific details of the DDGP regimens are shown in Table 1 . The cycle length was 21 days.

Response criteria. CT and magnetic resonance imaging (MRI) scans were employed to evaluate the treatment response every cycle and 1 month after the end of treatment according to adapted Cheson's standard criteria [17]. Complete response (CR) was defined as no evidence of residual disease; partial response (PR) was defined as a reduction of at least $50 \%$ of the pretreatment tumor burden; no response (NR) was defined as less than $50 \%$ tumor burden reduction or disease progression.

Assessment of toxicity of DDPG regimen. The toxicity of the DDPG regimen was assessed at each cycle from the first day of the regimen until one month after the last treatment. Adverse reactions were monitored by routine physical examination, biochemistry and hematological tests, urinalysis, and electrocardiogram (ECG); and graded according to the National Cancer Institute Common Terminology Criteria for Adverse Events, Version 4.0.

Data collection. Data from all patients were retrospectively collected with approval from the Ethics Committee of the First Affiliated Hospital of Zhengzhou University.

Statistical analysis. A univariate analysis to identify clinical factors predictive of treatment response was performed using Fisher's exact test on SPSS 15.0 software (SPSS Inc., Chicago, IL, USA). A $p$ value $<0.05$ was considered sufficient for statistical significance.

\section{Results}

Baseline characteristics of patients. The baseline characteristics of the 12 patients (six males and six females) are listed in Table 2. The median age was 54.5 years (range 28 - 64 years). At diagnosis, nine patients $(9 / 12,75.0 \%)$ had nasal presentation and three $(3 / 12,25.0 \%)$ had extra nasal presentation. For the nine patients with nasal presentation, the primary site was the nasal cavity; for the three patients with extra nasal presentation, the primary sites were the right colon, tonsil, 
Table 2. Patient characteristics, treatment, and response.

\begin{tabular}{|c|c|c|c|c|c|c|c|c|c|}
\hline No. & Sex & Age, year & Stage/Primary site & IPI score & $\begin{array}{c}\text { Systemic } \\
\text { B symptoms }\end{array}$ & $\begin{array}{l}\text { Elevated serum } \\
\text { LDH level }\end{array}$ & $\begin{array}{c}\text { Cycle } \\
\text { number }\end{array}$ & $\begin{array}{c}\text { Consolidation therapy } \\
\text { after remission }\end{array}$ & $\begin{array}{l}\text { Treatment } \\
\text { response }^{\mathrm{a}}\end{array}$ \\
\hline 1 & $\mathrm{M}$ & 58 & IV/Nasal cavity & 2 & $\mathrm{~N}$ & $\mathrm{~N}$ & 3 & RT, $50 \mathrm{~Gy}$ & CR \\
\hline 2 & M & 28 & III/Right colon & 2 & $\mathrm{Y}$ & $\mathrm{N}$ & 3 & - & CR \\
\hline 3 & M & 39 & II/Tonsil & 2 & $\mathrm{~N}$ & $\mathrm{~N}$ & 5 & RT, 50 Gy & CR \\
\hline 4 & $\mathrm{~F}$ & 44 & II/Pharyngeal jaw & 1 & $\mathrm{~N}$ & $\mathrm{~N}$ & 3 & RT, 45 Gy & CR \\
\hline 5 & M & 57 & II/Nasal cavity & 1 & $\mathrm{Y}$ & $\mathrm{N}$ & 3 & RT, 40 Gy & CR \\
\hline 6 & M & 57 & III/Nasal cavity & 3 & $\mathrm{~N}$ & $\mathrm{Y}$ & 2 & - & PR \\
\hline 7 & M & 35 & III/Nasal cavity & 2 & $\mathrm{Y}$ & $\mathrm{N}$ & 6 & - & CR \\
\hline 8 & $\mathrm{~F}$ & 52 & II/Nasal cavity & 1 & $\mathrm{~N}$ & $\mathrm{~N}$ & 3 & RT, 50 Gy & CR \\
\hline 9 & $\mathrm{~F}$ & 64 & IV/Nasal cavity & 3 & $\mathrm{Y}$ & $\mathrm{Y}$ & 6 & - & CR \\
\hline 10 & $\mathrm{~F}$ & 34 & III/Nasal cavity & 1 & $\mathrm{Y}$ & $\mathrm{N}$ & 6 & - & CR \\
\hline 11 & $\mathrm{~F}$ & 60 & II/Nasal cavity & 1 & $\mathrm{~N}$ & $\mathrm{~N}$ & 2 & RT, 50 Gy & PR \\
\hline 12 & $\mathrm{~F}$ & 60 & IV/Nasal cavity & 2 & $\mathrm{~N}$ & $\mathrm{Y}$ & 6 & - & CR \\
\hline
\end{tabular}

Abbreviations: IPI, the International Prognostic Index; LDH, lactate dehydrogenase; M, male; F, female; N, No; Y, Yes; RT, radiotherapy; CR, complete response; PR, partial response

a Treatment response indicates the response that was assessed one month after the end of treatment

and pharyngeal jaw, respectively. At the time of inclusion, five patients $(5 / 12,41.7 \%)$ had stage II disease and seven (7/12, $58.3 \%$ ) had stage III or IV disease. Systemic B symptoms were present in five patients $(5 / 12,41.7 \%)$ and the elevation of serum lactate dehydrogenase (LDH) levels were observed in three patients $(3 / 12,25.0 \%)$.

Treatment outcomes. The median cycle number of the DDGP regimen in the 12 patients was three (range two to six). All patients had an objective response to the regimen. The resulting treatment responses are shown in Table 2. One month after the end of treatment, ten patients (10/12, 83.3\%) achieved CR and two $(2 / 12,16.7 \%)$ patients achieved PR. The overall response rate (ORR) was $100 \%$. Seven patients $(7 / 12$, $58.3 \%)$ received irradiation as consolidation therapy after remission. In order to explore the clinical factors predictive of response, we performed a univariate analysis and found that the clinical factors including sex, age, stage of disease, International Prognostic Index (IPI) score, systemic B symptoms, and elevated serum LDH level were not predictive of the response to DDGP regimen in our patients.

The results of the long-term outcomes to DDGP regiment are presented in Table 4. The median follow-up for overall patients was 17 months (range $10-31$ months). Eight patients $(8 / 12,66.7 \%)$ were alive with no evidence of disease (NOD) after a median follow-up of 19 months (range 16 - 31 months). One patient $(1 / 12,8.3 \%)$ was alive with PR. Three patients $(3 / 12,25 \%)$ relapsed 6,7 , and 7.5 months after completing treatment with DDGP regimen, respectively. Of the three relapsed patients, one $(1 / 12,8.3 \%)$ was alive with disease recurrence and two $(2 / 12,16.7 \%)$ died of disease (DOD).

Example of DDGP regimen efficacy. Patient 1, a 58-yearold male, was diagnosed with ENKL, having a $\mathrm{CD} 3 \varepsilon+, \mathrm{CD} 2+$, granzyme-B+CD56+ phenotype, localized at the anterior nasal antrum (Figure 1A). He had no local symptoms apart from nasal obstruction and was admitted without fever. He received three courses of the DDGP regimen and then underwent radiotherapy (50 Gy) as consolidation therapy. CT examination before and after radiotherapy showed the disappearance of tumor lesions (Figures 1B and 1C). Currently, he is still in

Table 3. Univariate analysis of response to the DDGP regimen.

\begin{tabular}{lcccc}
\hline \multirow{2}{*}{ Factors } & \multirow{2}{*}{$\begin{array}{c}\text { Number } \\
\text { of patients }\end{array}$} & \multicolumn{3}{c}{ Treatment response a } \\
\cline { 5 - 5 } & & CR (\%) & PR (\%) & P value $^{\text {Sex }}$ \\
$\quad$ Male & 6 & $5(83.3)$ & $1(16.7)$ & 1.000 \\
$\quad$ Female & 6 & $5(83.3)$ & $1(16.7)$ & \\
Age & & & & \\
$\quad<50$ & 5 & $5(100)$ & $0(0)$ & 0.470 \\
$\quad 250$ & 7 & $5(71.4)$ & $2(28.6)$ & \\
Stage & & & & \\
$\quad$ II & 5 & $4(80.0)$ & $1(20.0)$ & 1.000 \\
$\quad$ III and IV & 7 & $6(85.7)$ & $1(14.3)$ & \\
IPI score & & & & \\
$\quad 1$ & 5 & $4(80.0)$ & $1(20.0)$ & 1.000 \\
$\quad 2-3$ & 7 & $6(85.7)$ & $1(14.3)$ & \\
Systemic B symptoms & & & & \\
$\quad$ Yes & 5 & $5(100)$ & $0(0)$ & 0.470 \\
$\quad$ No & 7 & $5(71.4)$ & $2(28.6)$ & \\
Elevated serum LDH level & & & & \\
$\quad$ Yes & 3 & $2(66.7)$ & $1(33.3)$ & 0.455 \\
$\quad$ No & 9 & $8(88.9)$ & $1(11.1)$ & \\
\hline
\end{tabular}

Abbreviations: CR, complete response; PR, partial response; IPI, the International Prognostic Index; LDH, lactate dehydrogenase

${ }^{a}$ Treatment response indicates the response that was assessed one month after the end of treatment 

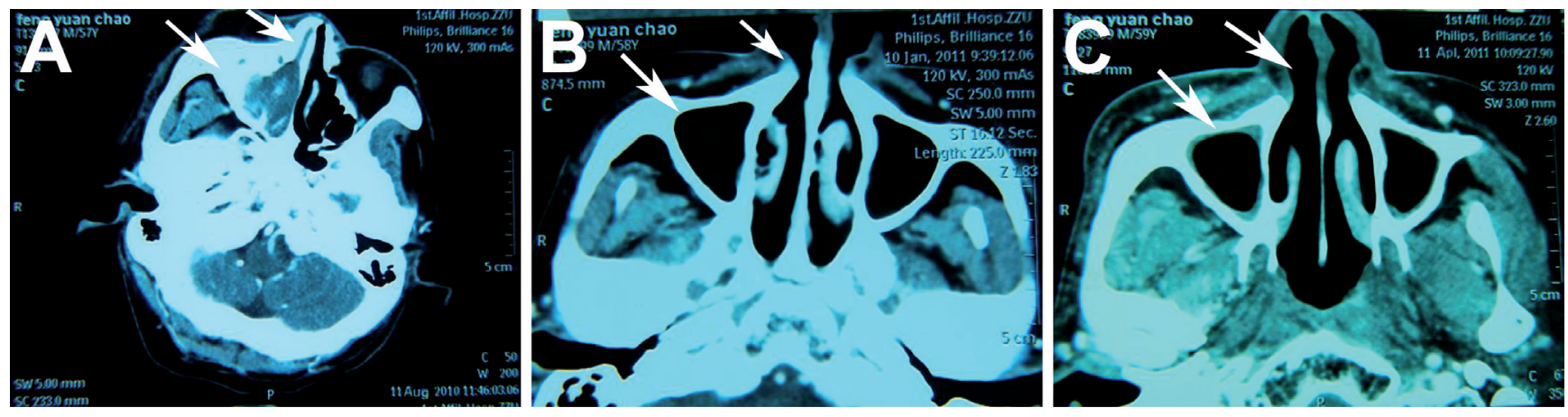

Figure 1. Efficacy of DDGP regimen in one representative patient (Patient 1, a 58-year-old male). (A) Axial CT image shows soft tissue masses (ENKL lesions) in the right nasal cavity, maxillary sinus, ethmoid sinus, and frontal sinus (indicated by white arrows) when he was admitted; (B) and (C) This patient received three courses of the DDGP regimen and then underwent radiotherapy $(50 \mathrm{~Gy})$ as consolidation therapy. CT images before (B) and after radiotherapy (C) show the disappearance of tumor lesions (indicated by white arrows). Currently, this patient is in CR with a follow-up of 31 months after the first course of the DDGP regimen

CR with a follow-up of 31 months after the first course of the DDGP regimen.

Toxicity. The toxicity profiles of the DDGP regimen are listed in Table 5. Only one patient $(1 / 12,8.3 \%)$ experienced mild allergic reactions. After oxygen inhalation, the symptoms including facial flushing and stuffiness disappeared in this patient. Hematologic toxicity was the most frequent toxicity in this study. All patients experienced varying degrees of leukopenia, neutropenia, thrombocytopenia, and anemia. Grade 3/4 leukopenia and neutropenia were common and both occurred in eight patients $(8 / 12,66.7 \%)$, respectively. Additionally, six patients $(6 / 12,50.0 \%)$ experienced grade $3 / 4$ thrombocytopenia and three $(3 / 12,25.0 \%)$ experienced grade $3 / 4$ anemia. However, no patient died of hematologic toxicity.

During the treatment, coagulation disorders occurring in patients included prolonged activated partial thromboplastin time (APTT), elevation of serum D-dimer levels, and venous thrombosis. Nevertheless, these adverse events were mild (grade 1/2) and no patients developed serious complications. For laboratory abnormalities, elevated alanine aminotransferase (ALT), total bilirubin, total cholesterol (TC), and blood urea nitrogen $(\mathrm{BUN})$ were observed in two patients $(2 / 12$, $16.7 \%$ ), but no patient experienced diabetes or pancreatitis.

Other toxicities included gastrointestinal and cardiac disorders. Eight patients $(8 / 12,66.7 \%)$ had varying degrees of nausea and vomiting. These symptoms were well controlled after the administration of serotonin receptor antagonists. Heart failure (grade 1/2) was observed in two patients complicated by heart diseases. After symptomatic treatment, significant recovery of cardiac functions was achieved in these patients.

\section{Discussion}

In this study, we have investigated the use of a PEG-Aspbased chemotherapy, a DDGP regimen, for the treatment of newly-diagnosed ENKL. In 12 patients, the ORR was 100\%

Table 4. Long-term outcomes of the DDGP regimen

\begin{tabular}{|c|c|c|c|c|}
\hline Patient No. & Follow-up, months & Relapse & Time of Relapse & Vital status at the end of follow-up \\
\hline 1 & 31 & $\mathrm{~N}$ & - & Alive, NOD \\
\hline 2 & 12 & $\mathrm{Y}$ & 7 months after completing treatment & DOD \\
\hline 3 & 30 & $\mathrm{~N}$ & - & Alive, NOD \\
\hline 4 & 24 & $\mathrm{Y}$ & 7.5 months after completing treatment & Alive with disease recurrence \\
\hline 5 & 26 & $\mathrm{~N}$ & - & Alive, NOD \\
\hline 6 & 10 & $\mathrm{Y}$ & 6 months after completing treatment & DOD \\
\hline 7 & 18 & $\mathrm{~N}$ & - & Alive, NOD \\
\hline 8 & 20 & $\mathrm{~N}$ & - & Alive, NOD \\
\hline 9 & 16 & $\mathrm{~N}$ & - & Alive, NOD \\
\hline 10 & 16 & $\mathrm{~N}$ & - & Alive, NOD \\
\hline 11 & 11 & $\mathrm{~N}$ & - & Alive with PR \\
\hline 12 & 16 & $\mathrm{~N}$ & - & Alive, NOD \\
\hline
\end{tabular}

Abbreviations: N, No; Y, Yes; NOD, no evidence of disease; DOD, died of disease; PR, partial response 
(83.3\% CR and 16.7\% PR); and eight patients (8/12, 66.7\%) were alive with NOD by the end of follow-up. Our results indicate that the DDGP regimen is effective in treating newlydiagnosed stage II - IV ENKL.

The enzyme L-Asp exerts its antitumor effects through the depletion of the essential amino acid L-asparagine, leading to inhibition of protein synthesis in tumor cells [18-21]. In vitro studies have demonstrated that L-Asp can induce apoptosis of chemotherapy-resistant tumoral NK cells, indicating it is not affected by multidrug resistance [22]. For the clinical use of L-Asp, Nagafuji et al. first reported the application of L-Asp in a patient with stage IV relapsed nasal natural killer/T-cell lymphoma after autologous peripheral blood stem cell transplantation [23]. Durable remission was achieved and this patient was alive with NOD at the time of the 18-month follow-up. Yong et al. first reported the clinical efficacy of L-Asp in patients with first-line CHOP-resistant ENKL [24]. Of a total of 33 patients, 17 achieved CR and the five-year OS rate was $55.9 \%$. Recently, a series of clinical studies have confirmed the remarkable efficacy of L-Asp-based regimens for the treatment of newly-diagnosed, relapsed, or refractory ENKLs [25-30]. Table 6 summarizes the latest published results (within five years) of L-Asp-based regimens for these diseases.

Although L-Asp-based regimens demonstrated to be significantly effective in treating ENKL, hypersensitivity reactions to L-Asp, considered to be associated with the immunogenicity of L-Asp and reported to occur in 3\% to $78 \%$ of patients, are of great concern because they are a potentially fatal complication during treatment [31-33]. To overcome this issue, the E. coli LAsp is modified by conjugation with PEG to produce PEG-Asp, which has a significant decrease in immunogenicity and high increase in drug stability. Currently, PEG-Asp, as an effective alternative for patients hypersensitive to the native enzyme, is being increasingly applied as a primary treatment regimen for leukemia $[13,34,35]$. Nevertheless, the application of PEG-Asp alone or PEG-Asp-based regimens for treating lymphoma has been rarely reported. Within the most recent five years, only one report exists on the clinical efficacy of PEG-Asp against ENKL [26]. For the two patients with stage I refractory ENKL, CR was achieved in both cases and one was alive with NOD by the end of follow-up (Table 6). Additionally, Zhang et al. reported that a DDGP regimen produced a high response rate and low recurrence rate in patients with subcutaneous panniculitis-like T-cell lymphomas, and its hematologic toxicity was well tolerated [36]. These findings indicate that PEG-Asp may be effective for the treatment of ENKL and thus warranted further investigation.

In this study, a DDGP regimen showed impressive clinical efficacy in the patients with newly-diagnosed stage II-IV ENKL. The ORR was $100 \%$ and the CR rate was $83.3 \%$, which were similar as well as better compared to results reported in previous studies on L-Asp-based regimens $[8,30]$. Eight patients were alive in continuous CR by the end of the follow-up, highlighting the favorable long-term outcome of this
Table 5. Toxicity profiles of the DDGP regimen

\begin{tabular}{lcc}
\hline Toxicity & All grades & Grades $\mathbf{3 / 4}$ \\
\hline Immune system disorders & 1 & 0 \\
$\quad$ Allergic reactions & 12 & \\
Hematologic toxicities & 12 & 8 \\
$\quad$ Leukopenia & 12 & 6 \\
Neutropenia & 12 & 3 \\
Thrombocytopenia & & \\
Anemia & 4 & 0 \\
Coagulation disorders & 4 & 0 \\
Prolonged APTT & 3 & 0 \\
Serum D-dimer elevation & & \\
$\quad$ Venous thrombosis & 2 & 0 \\
Laboratory abnormalities & 2 & 0 \\
$\quad$ ALT elevation & 2 & 0 \\
Serum bilirubin elevation & 2 & 1 \\
TC elevation & & 0 \\
BUN elevation & 8 & 0 \\
Gastrointestinal disorders & 8 & \\
Nausea & 2 & \\
Vomiting & & \\
Cardiac disorders & & \\
Heart failure & &
\end{tabular}

Abbreviations: APTT, activated partial thromboplastin time; ALT, alanine aminotransferase; TC, total cholesterol; BUN, blood urea nitrogen

regimen. Additionally, because of increased plasma half-life and reduced renal excretion, PEG-Asp in the DDGP regimen required much lower dosage and administration frequency than L-Asp in L-Asp-based regimens [37]. For example, the SMILE regimen (dexamethasone, methotrexate, ifosfamide, L-Asp, etoposide) requires intravenous injection of L-Asp at a dose of $6000 \mathrm{IU} / \mathrm{m}^{2}$ for six days in a 28-day cycle; while the DDGP regimen requires only one intramuscular injection of PEG-Asp at a dose of $2500 \mathrm{IU} / \mathrm{m}^{2}$ in a 21-day cycle, thus greatly enhancing the convenience and compliance of patients.

With regard to the toxicity profile of the DDPG regimen, the incidence of allergic reactions caused by hypersensitivity to PEG-Asp was very low, which may be attributed to the low immunogenicity of PEG-Asp. Hematological toxicity was the major concern using a DDPG regimen, although no hematological toxicity-related death occurred in the present study. Hematological toxicity may be caused by the myelosuppressive effects of gemcitabine and cyclophosphamide [38], thus indicating hematological parameters should be carefully monitored in patients receiving this regimen in order to avoid any severe unpredictable complications. Coagulation disorders were another concern, but these were mild and none led to serious clinical complications. Venous thrombosis was observed in three patients, which might be triggered by the hypercoagulable state in cancer patients and the inhibition of the synthesis of anticoagulant proteins caused by asparaginase [11]. However, detailed mechanisms still need to be investigated. 
Table 6. Literature review of the outcomes of PEG-Asp- or L-Asp-based regimen in the treatment of extranodal NK/T-cell lymphoma within five years

\begin{tabular}{|c|c|c|c|c|c|c|}
\hline $\begin{array}{l}\text { Author, year } \\
\text { (reference) }\end{array}$ & $\begin{array}{c}\text { Total number of } \\
\text { cases }\end{array}$ & $\begin{array}{c}\text { Stage } \\
\text { (number of cases) }\end{array}$ & $\begin{array}{c}\text { Previous treatment } \\
\text { (number of cases) }\end{array}$ & Regimen & Response & $\begin{array}{c}\text { Long-term } \\
\text { outcomes }\end{array}$ \\
\hline $\begin{array}{c}\text { Berk V, et al. } 2008 \\
\text { [19] }\end{array}$ & 1 & Stage IV & CHOP & $\begin{array}{c}\mathrm{L}-\mathrm{Asp}+\mathrm{VCR}+ \\
\text { PDNN }\end{array}$ & CR & NOD \\
\hline $\begin{array}{l}\text { Yamaguchi M, et al. } \\
2008[10]\end{array}$ & 6 & $\begin{array}{c}\text { Newly diagnosed } \\
\text { stage IV (3); } \\
\text { first relapse (2); } \\
\text { refractory to the } \\
1^{\text {st }} \text {-line therapy (1) }\end{array}$ & $\begin{array}{l}\text { N/A (3), CHOP-like } \\
\text { (2), DeVIC + RT (1) }\end{array}$ & SMILE & $\begin{array}{c}3 \mathrm{CR}+1 \mathrm{PR}+1 \mathrm{NE} \\
+1 \mathrm{NR}\end{array}$ & $1 \mathrm{DUD}+5 \mathrm{NE}$ \\
\hline $\begin{array}{c}\text { Jaccard A, et al. } \\
2009[25]\end{array}$ & 15 & $\begin{array}{l}\text { All cases were } \\
\text { relapsed or } \\
\text { refractory; stage } \\
\text { I (1); stage II/IIE } \\
\text { (4); stage IV (10) }\end{array}$ & $\begin{array}{l}\text { CHOP or CHOP- } \\
\text { like (12) }\end{array}$ & $\begin{array}{l}\text { L-Asp associated } \\
\text { with DXM, MTX, } \\
\text { or VLB }\end{array}$ & $\begin{array}{c}7 \mathrm{CR}+2 \mathrm{PR}+3 \mathrm{NR} \\
+3 \mathrm{NE}\end{array}$ & $\begin{array}{c}5 \mathrm{NOD}+6 \mathrm{DOD}+ \\
4 \mathrm{DUD}\end{array}$ \\
\hline $\begin{array}{c}\text { Yong W, et al. } 2009 \\
{[18]}\end{array}$ & 45 & $\begin{array}{l}\text { All cases were } \\
\text { relapsed or } \\
\text { refractory; I/II } \\
(33) ; \text { III/IV (12) }\end{array}$ & $\begin{array}{l}\text { CHOP or } \mathrm{CHOP}- \\
\text { like }(17)\end{array}$ & $\begin{array}{c}\text { L-Asp-based salvage } \\
\text { regimen }\end{array}$ & $\begin{array}{c}55.6 \% \mathrm{CR}+26.7 \% \\
\mathrm{PR}\end{array}$ & $\begin{array}{c}\text { Five-year OS rate } \\
\text { was } 66.9 \%\end{array}$ \\
\hline $\begin{array}{l}\text { Reyes VE Jr, et al. } \\
2010 \text { [26] }\end{array}$ & 2 & $\begin{array}{c}\text { Stage IAE, } \\
\text { refractory, (1); } \\
\text { stage IE, refractory, } \\
(1)\end{array}$ & $\mathrm{CHOP}+\mathrm{RT}(2)$ & PEG-Asp alone & $2 \mathrm{CR}$ & $1 \mathrm{NOD}+1 \mathrm{DOD}$ \\
\hline $\begin{array}{l}\text { Yamaguchi M, et al. } \\
2011 \text { [27] }\end{array}$ & 38 & $\begin{array}{c}\text { Newly diagnosed } \\
\text { stage IV (20); } \\
\text { first relapse (14); } \\
\text { refractory to the } \\
1^{\text {st }-l i n e ~ t h e r a p y ~(4) ~}\end{array}$ & $\begin{array}{c}\text { N/A (20), } \\
\text { CHOP-like (14), } \\
\text { DeVIC + RT (4) }\end{array}$ & SMILE & $\begin{array}{c}17 \mathrm{CR}+13 \mathrm{PR}+ \\
1 \mathrm{NR}+4 \mathrm{PD}+3 \mathrm{ED}\end{array}$ & $\begin{array}{c}\text { One-year OS rate } \\
\text { was } 55 \%\end{array}$ \\
\hline $\begin{array}{c}\text { Jaccard A, et al. } \\
2011 \text { [28] }\end{array}$ & 19 & $\begin{array}{l}\text { All cases were } \\
\text { relapsed or } \\
\text { refractory; stage } \\
\text { IE/IIE (12); stage } \\
\text { IV (7) }\end{array}$ & $\begin{array}{l}\text { CHOP or CHOP- } \\
\text { like (17), RT (9) }\end{array}$ & $\begin{array}{c}\text { DXM + MTX + } \\
\text { L-Asp }\end{array}$ & $\begin{array}{c}11 \mathrm{CR}+3 \mathrm{PR}+4 \\
\mathrm{NR}+1 \mathrm{NE}\end{array}$ & $\begin{array}{c}8 \mathrm{NOD}+10 \mathrm{DOD} \\
+1 \mathrm{DUD}\end{array}$ \\
\hline $\begin{array}{c}\text { Kwong YL, et al. } \\
2012 \text { [9] }\end{array}$ & 87 & $\begin{array}{l}\text { Newly diagnosed: } \\
\text { stage I (12), stage } \\
\text { II (5), stage IV } \\
(26) \text {; relapsed/ } \\
\text { refractory: stage } \\
\text { I (13), stage II (8), } \\
\text { stage III (2), stage } \\
\text { IV (21) }\end{array}$ & $\begin{array}{l}\text { CHOP or CHOP- } \\
\text { like (30); CHOP or } \\
\text { CHOP-like + RT } \\
\text { (7); CCRT (5) }\end{array}$ & SMILE & $66 \% \mathrm{CR}+15 \% \mathrm{PR}$ & $\begin{array}{c}\text { Five-year OS rate } \\
\text { was } 50 \% \text { and } 4 \text {-year } \\
\text { DFS rate was } 64 \%\end{array}$ \\
\hline $\begin{array}{c}\text { Jiang M, et al. } 2012 \\
\text { [8] }\end{array}$ & 26 & $\begin{array}{c}\text { Newly diagnosed: } \\
\text { stage IE (20), IIE } \\
(6)\end{array}$ & $\mathrm{N} / \mathrm{A}$ & $\begin{array}{c}\mathrm{L}-\mathrm{Asp}+\mathrm{VCR}+ \\
\text { PDN }\end{array}$ & $\begin{array}{c}21 \mathrm{CR}+2 \mathrm{PR}+ \\
3 \mathrm{PD}\end{array}$ & $\begin{array}{c}\text { Two-year OS rate } \\
\text { was } 88.5 \% \text {, and } 2- \\
\text { year PFS rate was } \\
\quad 80.6 \%\end{array}$ \\
\hline $\begin{array}{c}\text { Ahn HK, et al. } 2013 \\
{[29]^{\text {a }}}\end{array}$ & 1 & IVB, relapsed & $\begin{array}{l}\text { CCRT followed by } \\
\text { VIDL; MIDLE }\end{array}$ & L-Asp + GEM & Death & $\begin{array}{c}\text { PFS: } 0.6 \text { month; OS: } \\
0.6 \text { month }\end{array}$ \\
\hline $\begin{array}{c}\text { Wang L, et al. } 2013 \\
\text { [30] }\end{array}$ & 27 & $\begin{array}{l}\text { Newly diagnosed: } \\
\text { stage IE (18), } \\
\text { IIE(9) }\end{array}$ & $\mathrm{N} / \mathrm{A}$ & $\begin{array}{c}\text { GEM + L-Asp + } \\
\text { OXA }\end{array}$ & $20 \mathrm{CR}+6 \mathrm{PR}$ & $\begin{array}{l}4 \text { DOD. Two-year } \\
\text { OS and PFS rates } \\
\text { were } 86 \% \text {. }\end{array}$ \\
\hline
\end{tabular}

a Twenty patients were reported in this literature but only one received an L-Asp-based regimen

Abbreviations: CHOP, cyclophosphamide + doxorubicin + vincristine + prednisone; DeVIC, carboplatine + etoposide + ifosfamide + dexamethasone; SMILE, dexamethasone + methotrexate + ifosfamide + L-asparaginase + etoposide; CCRT, concurrent chemoradiotherapy; VIDL, etoposide + ifosfamide + L-Asp + dexamethasone; MIDLE, methotrexate + ifosfamide + dexamethasone + L-Asp + etoposide; VCR, vincristine; PDNN, prednisolone; DXM, dexamethasone; MTX, methotrexate; VLB, vinblastine; PDN, prednisone; GEM, gemcitabine; OXA, oxaliplatin; RT, radiotherapy; CR, complete response; PR, partial response; ED, early death; NE, not evaluated; NR no response; NOD, no evidence of disease; DOD, died of disease; DUD, dead unrelated to disease; OS, overall survival; DFS, disease-free survival; PFS, progression-free survival 
In conclusion, our study shows significant efficacy and safety of PEG-Asp-based DDGP regimen in treating patients with newly-diagnosed stage II-IV ENKL, and indicates the potential of this regimen as a first-line therapy against this disease. The retrospective nature, small sample size, and short follow-up period suggest that our findings need to be further investigated using a prospective study with a larger patient group and longer follow-up period. Furthermore, the efficacy of DDGP regimen against relapsed or refractory ENKL is still unclear. A clinical study is now in progress to evaluate its efficiency in the treatment of this disease.

Acknowledgements: All authors would like to thank Dr. Fang Wang for her help in preparing the manuscript.

\section{References}

[1] AOZASA K, ZAKI MA. Epidemiology and pathogenesis of nasal NK/T-cell lymphoma: a mini-review. ScientificWorldJournal 2011; 11: 422-428. http://dx.doi. org/10.1100/tsw.2011.41

[2] EMILE JF, BOULLAND ML, HAIOUN C, KANAVAROS P, PETRELLA T, et al. CD5-CD56+ T-cell receptor silent peripheral T-cell lymphomas are natural killer cell lymphomas. Blood 1996; 87: 1466-1473.

[3] SUZUKI R. NK/T-cell lymphomas: pathobiology, prognosis and treatment paradigm. Curr Oncol Rep 2012; 14: 395-402. http://dx.doi.org/10.1007/s11912-012-0245-9

[4] KWONG YL. The diagnosis and management of extranodal NK/T-cell lymphoma, nasal-type and aggressive NK-cell leukemia. J Clin Exp Hematop 2011; 51: 21-28. http://dx.doi. org/10.3960/jslrt.51.21

[5] CHAN JKC, QUINTANILLA-MARTINEZ L, FERRY JA, PEH S-C. Extranodal NK/T-cell lymphoma, nasal type. In: Swerdlow SH, Campo E, Harris NL, et al, editors. WHO Classification of Tumours of Haematopoietic and Lymphoid Tissue (IARC WHO Classification of Tumours), 4th ed, Lyon: IARC Press; 2008: 285-288.

[6] KWONG YL, ANDERSON BO, ADVANI R, KIM WS, LEVINE AM, et al. Management of T-cell and natural-killercell neoplasms in Asia: consensus statement from the Asian Oncology Summit 2009. Lancet Oncol 2009; 10: 1093-1101. http://dx.doi.org/10.1016/S1470-2045(09)70265-7

[7] KIM BS, KIM TY, KIM CW, KIM JY, HEO DS, et al. Therapeutic outcome of extranodal NK/T-cell lymphoma initially treated with chemotherapy--result of chemotherapy in NK/Tcell lymphoma. Acta Oncol 2003; 42: 779-783. http://dx.doi. org/10.1080/02841860310010682

[8] JIANG M, ZHANG H, JIANG Y, YANG Q, XIE L, et al. Phase 2 trial of „sandwich“ L-asparaginase, vincristine, and prednisone chemotherapy with radiotherapy in newly diagnosed, stage IE to IIE, nasal type, extranodal natural killer/T-cell lymphoma. Cancer 2012; 118: 3294-3301. http://dx.doi.org/10.1002/cncr.26629

[9] KWONG YL, KIM WS, LIM ST, KIM SJ, TANG T, et al. SMILE for natural killer/T-cell lymphoma: analysis of safety and efficacy from the Asia Lymphoma Study Group. Blood
2012; 120: 2973-2980. http://dx.doi.org/10.1182/blood-201205-431460

[10] YAMAGUCHI M, SUZUKI R, KWONG YL, KIM WS, HASEGAWA Y, et al. Phase I study of dexamethasone, methotrexate, ifosfamide, L-asparaginase, and etoposide (SMILE) chemotherapy for advanced-stage, relapsed or refractory extranodal natural killer (NK)/T-cell lymphoma and leukemia. Cancer Sci 2008; 99: 1016-1020. http://dx.doi.org/10.1111/ j.1349-7006.2008.00768.x

[11] CHABNER BA, FRIEDMANN AM. Asparaginase. In: Chabner BA and Longo DL, editors. Cancer Chemotherapy and Biotherapy: Principles and Practice, 5th ed. Philadelphia: Lippincott Williams \& Wilkins; 2011: 411-417.

[12] COOPERATION GROUP OF PHASE IICTOPEGA. Comparison of polyethylene glycol conjugated asparaginase and L-asparaginase for treatment of childhood acute lymphoblastic leukemia. Zhonghua Xue Ye Xue Za Zhi 2008; 29: 29-33.

[13] FULLMER A, O'BRIEN S, KANTARJIAN H, JABBOUR E. Novel therapies for relapsed acute lymphoblastic leukemia. Curr Hematol Malig Rep 2009; 4: 148-156. http://dx.doi. org/10.1007/s11899-009-0021-6

[14] FARID M, YAU YW, TAY K, QUEK R, TAO M, et al. A promising new regimen for the treatment of advanced extranodal NK/T cell lymphoma. Acta Oncol 2011; 50: 589-590. http:// dx.doi.org/10.3109/0284186X.2010.516272

[15] HEMPEL G, MULLER HJ, LANVERS-KAMINSKY C, WURTHWEIN G, HOPPE A, et al. A population pharmacokinetic model for pegylated-asparaginase in children. $\mathrm{Br}$ J Haematol 2010; 148: 119-125. http://dx.doi.org/10.1111/ j.1365-2141.2009.07923.x

[16] MASETTI R, PESSION A. First-line treatment of acute lymphoblastic leukemia with pegasparaginase. Biologics 2009; 3: 359-368.

[17] CHESON BD, PFISTNER B, JUWEID ME, GASCOYNE $\mathrm{RD}$, SPECHT L, et al. Revised response criteria for malignant lymphoma. J Clin Oncol 2007; 25: 579-586. http://dx.doi. org/10.1200/JCO.2006.09.2403

[18] YONG W, ZHENG W, ZHU J, ZHANG Y, WANG X, et al. $\mathrm{L}$-asparaginase in the treatment of refractory and relapsed extranodal NK/T-cell lymphoma, nasal type. Ann Hematol 2009; 88: 647-652. http://dx.doi.org/10.1007/s00277-008$\underline{0669-3}$

[19] BERK V, YILDIZ R, AKDEMIR UO, AKYUREK N, KARABACAK NI, et al. Disseminated extranodal NK/T-cell lymphoma, nasal type, with multiple subcutaneous nodules: utility of 18F-FDG PET in staging. Clin Nucl Med 2008; 33: 365-366. http://dx.doi.org/10.1097/RLU.0b013e31816a7a23

[20] YOKOYAMA H, YAMADA MF, ISHIZAWA K, YAMAMOTO J, TOMIYA Y, et al. Successful treatment of advanced extranodal NK/T cell lymphoma with unrelated cord blood transplantation. Tohoku J Exp Med 2007; 211: 395-399. http://dx.doi.org/10.1620/tjem.211.395

[21] OBAMA K, TARA M, NIINA K. L-asparaginase-Based induction therapy for advanced extranodal NK/T-cell lymphoma. Int J Hematol 2003; 78: 248-250. http://dx.doi.org/10.1007/ $\underline{\mathrm{BF} 02983802}$ 
[22] CHARAMELLA LJ, MEYER C, THOMPSON GE, DIMITROV NV. Chemotherapeutic agents and modulation of natural killer cell activity in vitro. J Immunopharmacol 1985; 7: 53-65. http://dx.doi.org/10.3109/08923978509026469

[23] NAGAFUJI K, FUJISAKI T, ARIMA F, OHSHIMA K. Lasparaginase induced durable remission of relapsed nasal NK/T-cell lymphoma after autologous peripheral blood stem cell transplantation. Int J Hematol 2001; 74: 447-450. http:// dx.doi.org/10.1007/BF02982090

[24] YONG W, ZHENG W, ZHANG Y. Clinical characteristics and treatment of midline nasal and nasal type NK/T cell lymphoma. Zhonghua Yi Xue Za Zhi 2001; 81: 773-775.

[25] JACCARD A, PETIT B, GIRAULT S, SUAREZ F, GRESSIN $\mathrm{R}$, et al. L-asparaginase-based treatment of 15 western patients with extranodal NK/T-cell lymphoma and leukemia and a review of the literature. Ann Oncol 2009; 20: 110-116. http://dx.doi.org/10.1093/annonc/mdn542

[26] REYES VE, JR., AL-SALEEM T, ROBU VG, SMITH MR. Extranodal NK/T-cell lymphoma nasal type: efficacy of pegaspargase. Report of two patients from the United Sates and review of literature. Leuk Res 2010; 34: e50-54. http:// dx.doi.org/10.1016/j.leukres.2009.09.002

[27] YAMAGUCHI M, KWONG YL, KIM WS, MAEDA Y, HASHIMOTO C, et al. Phase II study of SMILE chemotherapy for newly diagnosed stage IV, relapsed, or refractory extranodal natural killer (NK)/T-cell lymphoma, nasal type: the NK-Cell Tumor Study Group study. J Clin Oncol 2011; 29: 4410-4416. http://dx.doi.org/10.1200/JCO.2011.35.6287

[28] JACCARD A, GACHARD N, MARIN B, ROGEZ S, AUDRAIN M, et al. Efficacy of L-asparaginase with methotrexate and dexamethasone (AspaMetDex regimen) in patients with refractory or relapsing extranodal NK/T-cell lymphoma, a phase 2 study. Blood 2011; 117: 1834-1839. http://dx.doi. org/10.1182/blood-2010-09-307454

[29] AHN HK, KIM SJ, HWANG DW, KO YH, TANG T, et al. Gemcitabine alone and/or containing chemotherapy is efficient in refractory or relapsed NK/T-cell lymphoma. Invest New Drugs 2013; 31: 469-472. http://dx.doi.org/10.1007/s10637$\underline{012-9889-4}$

[30] WANG L, WANG ZH, CHEN XQ, LI YJ, WANG KF, et al. First-line combination of gemcitabine, oxaliplatin, and Lasparaginase (GELOX) followed by involved-field radiation therapy for patients with stage IE/IIE extranodal natural killer/ T-cell lymphoma. Cancer 2013; 119: 348-355. http://dx.doi. org/10.1002/cncr.27752

[31] ZAKARIJA A, KWAAN HC. Adverse effects on hemostatic function of drugs used in hematologic malignancies. Semin Thromb Hemost 2007; 33: 355-364. http://dx.doi.org/10.1055/ s-2007-976171

[32] SOYER OU, AYTAC S, TUNCER A, CETIN M, YETGIN $\mathrm{S}$, et al. Alternative algorithm for L-asparaginase allergy in children with acute lymphoblastic leukemia. J Allergy Clin Immunol 2009; 123: 895-899. http://dx.doi.org/10.1016/ j.jaci.2008.10.034

[33] WACKER P, LAND VJ, CAMITTA BM, KURTZBERG J, PULLEN J, et al. Allergic reactions to E. coli L-asparaginase do not affect outcome in childhood B-precursor acute lymphoblastic leukemia: a Children's Oncology Group Study. J Pediatr Hematol Oncol 2007; 29: 627-632. http://dx.doi. org/10.1097/MPH.0b013e3181483df1

[34] SILVERMANLB,SUPKOJG,STEVENSONKE, WOODWARD C, VROOMAN LM, et al. Intravenous PEG-asparaginase during remission induction in children and adolescents with newly diagnosed acute lymphoblastic leukemia. Blood 2010; 115: 1351-1353. http://dx.doi.org/10.1182/blood-2009-09$\underline{245951}$

[35] HAWKINS DS, PARK JR, THOMSON BG, FELGENHAUER JL, HOLCENBERG JS, et al. Asparaginase pharmacokinetics after intensive polyethylene glycol-conjugated L-asparaginase therapy for children with relapsed acute lymphoblastic leukemia. Clin Cancer Res 2004; 10: 5335-5341. http://dx.doi. org/10.1158/1078-0432.CCR-04-0222

[36] ZHANG M, QIU Y, LI W, WANG G, LI L. Analysis of Six Cases of Subcutaneous Panniculitis-like T-cell Lymphoma. Chinese Journal of Clinical Oncology. 2011; 18: 1111-1113.

[37] VAN DEN BERG H. Asparaginase revisited. Leuk Lymphoma 2011; 52: 168-178. http://dx.doi.org/10.3109/ $\underline{10428194.2010 .537796}$

[38] MAHADEVAN D, UNGER JM, SPIER CM, PERSKY DO, YOUNG F, et al. Phase 2 trial of combined cisplatin, etoposide, gemcitabine, and methylprednisolone (PEGS) in peripheral T-cell non-Hodgkin lymphoma: Southwest Oncology Group Study S0350. Cancer 2013; 119: 371-379. http://dx.doi. org/10.1002/cncr.27733 